\title{
Lung Disease in Mice with Cystic Fibrosis
}

\author{
Geraldine Kent, ${ }^{\star}$ Richard lles, ${ }^{\star \ddagger}$ Christine E. Bear, ${ }^{\S}$ Ling-Jun Huan, ${ }^{\S}$ Uta Griesenbach, ${ }^{*}$ Colin McKerlie, ${ }^{\star \star}$ Helena Frndova, ${ }^{*}$ \\ Cameron Ackerley, " Diane Gosselin, ${ }^{\ddagger}$ Danuta Radzioch, ${ }^{\ddagger \ddagger}$ Hugh O’Brodovich, ${ }^{* \neq}$ Lap-Chee Tsui, ${ }^{* \|}$ Manuel Buchwald, ${ }^{* \|}$ \\ and A. Keith Tanswell ${ }^{\star \ddagger}$ \\ * Research Institute, Hospital for Sick Children, Toronto, Ontario M5G 1 X8, Canada $;{ }^{\ddagger}$ Department of Paediatrics, ${ }^{\S}$ Department of Cell \\ Biology, "Department of Molecular and Medical Genetics, and "Department of Pathology, University of Toronto, Toronto, Ontario M5S \\ 1 A8 Canada; **Research Services and Department of Pathology, Sunnybrook Health Sciences Centre, North York, Ontario M4N 3M5, \\ Canada; and ${ }^{\ddagger}$ Montreal General Hospital Research Institute, McGill Centre for Study of Host Resistance, McGill University, Montreal, \\ Quebec H3G 1A4, Canada
}

\begin{abstract}
The leading cause of mortality and morbidity in humans with cystic fibrosis is lung disease. Advances in our understanding of the pathogenesis of the lung disease of cystic fibrosis, as well as development of innovative therapeutic interventions, have been compromised by the lack of a natural animal model. The utility of the CFTR-knockout mouse in studying the pathogenesis of cystic fibrosis has been limited because of their failure, despite the presence of severe intestinal disease, to develop lung disease. Herein, we describe the phenotype of an inbred congenic strain of CFTR-knockout mouse that develops spontaneous and progressive lung disease of early onset. The major features of the lung disease include failure of effective mucociliary transport, postbronchiolar over inflation of alveoli and parenchymal interstitial thickening, with evidence of fibrosis and inflammatory cell recruitment. We speculate that the basis for development of lung disease in the congenic CFTR-knockout mice is their observed lack of a non-CFTR chloride channel normally found in CFTR-knockout mice of mixed genetic background. (J. Clin. Invest. 1997. 100:3060-3069.) Key words: lung mechanics • ion transport • obstructive airway disease • pulmonary fibrosis $\bullet$ chloride channels
\end{abstract}

\section{Introduction}

Lung disease remains the leading cause of severe illness and death in patients with cystic fibrosis $(\mathrm{CF}),{ }^{1}$ and the most common recessively inherited disorder in Caucasian populations $(1,2)$. CF is caused (3) by mutations in the CF transmembrane conductance regulator gene $(C F T R)$. The protein product of

Address correspondence to Dr. A.K. Tanswell, Division of Neonatology, Hospital for Sick Children, 555 University Avenue, Toronto, Ontario M5G 1X8, Canada. Phone: 416-813-6344; FAX: 416-8135002; E-mail: keitht@sickkids.on.ca

Received for publication 31 March 1997 and accepted in revised form 9 October 1997.

1. Abbreviations used in this paper: $\mathrm{CF}$, cystic fibrosis; $\mathrm{C}_{\mathrm{rs}}$, respiratory system compliance; FVC, forced vital capacity; PAS, Periodic AcidSchiff; PD, potential difference; $\mathrm{R}_{\mathrm{rs}}$, respiratory system resistance; TLC, total lung capacity; $\mathrm{t}_{\mathrm{rs}}$, flow-volume relationship.

J. Clin. Invest.

(C) The American Society for Clinical Investigation, Inc. 0021-9738/97/12/3060/10 \$2.00

Volume 100, Number 12, December 1997, 3060-3069

http://www.jci.org
CFTR is a $\mathrm{Cl}^{-}$channel, and the resultant inadequate $\mathrm{Cl}^{-}$transport in epithelia of $\mathrm{CF}$ patients is assumed to be the initiating cause of the chronic pathological sequelae of CF (4). The intermediate steps between a failure of $\mathrm{Cl}^{-}$transport and the development of lung disease have not been completely elucidated. Longitudinal studies of affected humans have provided some insights into the possible pathogenesis of their lung disease (5-7), but progress has been hampered by the lack of any natural animal model. The first knockout strain of mice lacking functional CFTR (designated $C f t r^{m 1 U N C}$ ) were produced at the University of North Carolina in $1992(8,9)$. Unexpectedly, these mice failed to develop lung pathology, even in adulthood, despite severe bowel disease $(8,9)$.

Rozmahel et al. (10), using another strain of knockout mice lacking CFTR ( $\left.C f t r^{m 1 H S C} / C f t r^{m 1 H S C}\right)$, demonstrated that there was a difference in severity of intestinal disease between $\mathrm{CF}$ mice of different genetic backgrounds. These authors suggested that modifier genes could be upregulated in $\mathrm{CF}$, which would directly or indirectly partially correct the abnormalities of $\mathrm{Na}^{+}$and $\mathrm{Cl}^{-}$epithelial ion transport. These included a non-CFTR $\mathrm{Cl}^{-}$conductance gene, the activity of which could compensate, in part, for the lack of intestinal CFTR. We hypothesized that the mixed genetic background of the original Cftr ${ }^{m l U N C}$ strain could similarly influence the development of lung pathology. To produce animals of a single genetic background (congenic), heterozygous mice from the original outbred colony $\left(C f t r^{m 1 U N C}\right)$ were bred into a C57BL/6J background (C57BL/6J Cftr ${ }^{m 1 U N C} / C f t^{m 1 U N C}$ ) by serial backcrossing. CF mice are severely affected by intestinal disease, and the majority die from intestinal obstruction during the 3-wk period after weaning. As in our previous studies with $\mathrm{CF}$ mice, we used a nutrient liquid diet to prolong survival (11). We observed that the surviving congenic mice consistently develop spontaneous and progressive lung disease. Lung histology was examined at $21 \mathrm{~d}$ to 6 mo after birth by both light and electron microscopy. Pulmonary function tests and measurements of nasal potential difference (PD) were also performed.

\section{Methods}

Animals. Animal housing conditions, diet, and tail clip analyses for genotype have been reported in detail elsewhere (11). Heterozygous $C f t^{m I U N C}$ mice (courtesy of Dr. Beverly Koller, University of North Carolina, Chapel Hill, NC) were bred into a C57BL/6J background through backcrossing to wild type C57BL/6J mice (The Jackson Laboratory, Bar Harbor, ME). Heterozygous mice were identified in each generation by PCR, using primers specific for the endogenous CFTR locus and for the mutant CFTR locus: Primer A (wild type) 5'CTGTAGTTGGCAAGCTTTGAC3'; Primer A (mutant) 5'ACACTGCTCGAGGGCTAGCCTCTTC3'; Primer B (wild type and mutant) 5'CAGTGAAGCTGAGACTGTGAGCTT3'. The degree of 
C57BL/6J genetic background was determined through microsatellite marker typing in generations 2, 3, and 4. A total of 66 informative microsatellite markers, distributed over the entire genome, were tested. In each generation, the mouse with the highest degree of B6 genetic background was chosen for subsequent breeding. In generation 4, three out of five pups showed $100 \%$ homozygocity for B6 alleles. Breeding was then continued for another 14 generations.

Microsatellite typing. High molecular weight genomic DNA was prepared from tail tissue through a modification of the salting out procedure (12). Briefly, tails $(2 \mathrm{~cm})$ were digested overnight at $55^{\circ} \mathrm{C}$ with proteinase $\mathrm{K}(0.5 \mathrm{mg} / \mathrm{ml})$. Proteins were then precipitated with a saturated $\mathrm{NaCl}$ solution followed by centrifugation at 13,000 rpm for $10 \mathrm{~min}$. DNA was ethanol precipitated and redissolved in Tris-EDTA buffer. PCR reactions were performed as described by O'Brien et al. (13). Primers were used under standardized conditions: $2 \mathrm{mM} \mathrm{MgCl}_{2}$, $200 \mu \mathrm{M}$ dNTP, $100 \mathrm{nM}$ primers, $20 \mathrm{ng}$ genomic DNA, and $1 \mathrm{U}$ Taq polymerase. The reverse primer was $5^{\prime}$ end-labeled with $\gamma\left[{ }^{32} \mathrm{P}\right] \mathrm{ATP}$ using T4 polynucleotide kinase. $5 \mathrm{nmol}$ of the labeled primers were added to the PCR reaction. Thermal cycling was carried out for 35 cycles $\left(1 \mathrm{~min}, 94^{\circ} \mathrm{C} ; 1 \mathrm{~min}, 50^{\circ} \mathrm{C} ; 1 \mathrm{~min}, 72^{\circ} \mathrm{C}\right)$. PCR products were diluted in $100 \%$ formamide and denatured for $2 \mathrm{~min}$ at $95^{\circ} \mathrm{C}$. Electrophoresis was performed in $6 \%(\mathrm{wt} / \mathrm{vol})$ polyacrilamide gels containing $8 \mathrm{M}$ urea. Gels were dried for autoradiographic analysis (BIOMAX film).

Screening for infection. Immediately before animals were examined histologically, a routine serology surveillance was performed on the entire colony using sentinel mice (CD-1 strain) which had been placed in open cages in the rooms for three months and then exsanguinated under general anesthesia. The sera from these animals was frozen and shipped to the University of Missouri Research Animal Diagnostics Laboratory (Columbia, MO) to be screened for rodent viral pathogens (mouse hepatitis, Sendai, mouse pneumonia, respiratory enteric orphan, ectromelia, Theiler's murine encephalitis, mouse adenoviruses 1 and 2, lymphocytic choriomeningitis, infant mouse enzootic diarrhea, polyoma, and parvoviruses), Carbacillus and Mycoplasma pulmonis. These animals were immediately adjacent to another group of sentinel mice that were maintained under the same conditions for a further $6 \mathrm{wk}$. Half of these animals were screened as above, as were animals from all other mouse rooms (including immuno-compromised colonies) in our animal facility. The remaining sentinel mice, four congenic C57BL/6J CF mice and four C57BL/6J heterozygotic $\mathrm{CF}$ mouse breeders, were submitted alive to the Ontario Veterinary College Department of Pathology, University of Guelph (Guelph, Ontario, Canada) for histopathological screening of kidneys, lungs, heart, spleen, pancreas, salivary glands, jejunum, ileum, colon, brain, seminal vesicles, thymus, and lymph nodes. Lung and jejunal tissue were cultured for aerobic and anaerobic bacteria.

Preparation of samples for microscopy. 18 C57BL/6J CftrmlUNC/ $C f t r^{m I U N C}$ mice were studied. Nine heterozygous $C f t r^{m I U N C}$ mice and nine wild-type C57BL/6J age-matched were used as controls. Five of the C57BL/6J age-matched controls were maintained on the same liquid diet, and four were fed solid chow. Animals were anesthetized with $30 \mathrm{mg} / \mathrm{kg}$ intraperitoneal chloral hydrate (Allan and Hanbury, Toronto, Canada). The chest was opened and the trachea exposed. In the animals used for electron microscopic examination, fixative was instilled into the trachea, through a needle, until the lungs inflated and there was back flow through the nares. The trachea was then quickly ligated. The fixative used was $1 \%$ glutaraldehyde (vol/vol) and $4 \%$ (vol/vol) paraformaldehyde in $0.1 \mathrm{M}$ phosphate buffer. The lungs were then excised and submerged in fixative. The seven lungs used for light microscopic examination were perfused with $10 \%$ (vol/ vol) neutral buffered formalin, then fixed for $3 \mathrm{~d}$ under $5 \mathrm{~cm} \mathrm{H}_{2} \mathrm{O}$ pressure. The lungs were then embedded in paraffin for sectioning and staining. For the study of sinuses, heads from animals in all three groups were fixed in $10 \%(\mathrm{vol} / \mathrm{vol})$ neutral buffered formalin, then decalcified in $8 \%(\mathrm{vol} / \mathrm{vol})$ formic acid for $3 \mathrm{~d}$ before being embedded in paraffin for sectioning and staining. Sections were stained with hematoxylin and eosin, PAS, or Masson's trichrome.
Both scanning and transmission electron microscopy (ScEM and TrEM) were performed. The lungs were fixed for $4 \mathrm{~h}$, washed with buffer, and post fixed with phosphate-buffered $\mathrm{O}_{2} \mathrm{O}_{4}$. Samples were dehydrated in an ascending series of ethanols. ScEM samples were then critical point dried and rendered conductive with a thin layer of gold. TrEM samples were embedded in epon-araldite via propylene oxide. Ultrathin sections exhibiting a pale gold interference color were mounted on grids and stained with uranyl acetate and lead citrate. These specimens were then examined and photographed. Digital images were obtained for both sets of samples and morphometry performed using an image analysis program (NIH image 1.59; National Institutes of Health, Bethesda, MD). A minimum of 25 fields were analyzed, for each of 3 animals, to determine the percentage of terminal bronchiolar cells which were of a nonciliated cell type and the interalveolar interstitial macrophage and fibroblast density per $\mathrm{mm}^{2}$. Results are shown as mean $\pm \mathrm{SD}$, and statistical comparisons at single time points were made using Student's $t$ test.

Pulmonary function tests. Five C57BL/6J Cftr ${ }^{m 1 U N C} / C f t r^{m l U N C}$ mice were anesthetized as above and tracheotomized with a 4-French Angiocath. 21 age- (6-9 mo) and sex-matched wild-type control C57BL/ $6 \mathrm{~J}$ mice, and five heterozygous $C f^{m} r^{m I U N C}$ mice, aged 3-4 mo with body weights intermediate between the other two groups, were similarly anesthetized and used as controls. The animals were paralyzed with $0.1 \mathrm{mg} / \mathrm{kg}$ intraperitoneal pancuronium (Pavulon; Organon, Scarborough, Ontario, Canada), placed in a plethysmographic box $\left(300 \mathrm{~cm}^{3}\right)$, and ventilated with an infant ventilator (Model IV_100B; Sechrist Industries, Inc., Anaheim, CA) at a tidal volume of $0.25 \pm 0.01$ $\mathrm{ml}$ (mean \pm SEM) with $100 \%$ oxygen. Changes in plethysmography box flow and volume were recorded using a pneumotachograph with a dead space of $0.3 \mathrm{ml}$ (8430B; Hans Rudolf, Inc., Kansas City, MO), connected to a pressure transducer (Validyne MP 45; Validyne Engineering Corp., Northridge, CA) with a linear range of 0-2 $\mathrm{cm} \mathrm{H}_{2} \mathrm{O}$ ). Airway pressure at the mouth was measured using a second pressure transducer (Validyne MP 45; Validyne Engineering Corp.) with a linear range of $0-30 \mathrm{~cm} \mathrm{H}_{2} \mathrm{O}$. Signals from the pressure transducers were passed via a 12 bit A-D board (Transduction, Mississauga, Ontario, Canada), to a computer for analysis using the Anadat computer program software (Baker Instruments, Concord, Ontario). Weight, respiratory system compliance $\left(\mathrm{C}_{\mathrm{rs}}\right)$, resistance $\left(\mathrm{R}_{\mathrm{rs}}\right)$, and forced vital capacity (FVC) were measured for all animals. Maximal flows through endotracheal tubes alone were measured for the various deflation pressures. The resistance of the circuit was found to be flow-dependent, ranging from $2-5 \mathrm{~cm} \mathrm{H}_{2} \mathrm{O}^{-1} / \mathrm{ml} / \mathrm{s}$. A 1.5 -liter perspex box was used to contain the negative pressure, generated and regulated from wall source. Three computer-activated solenoids (Cole Palmer Instruments, Vernon Hills, IL) were placed in the expiratory limb of the circuit. When activated at full inspiration the first solenoid occluded the inspiratory/expiratory line of the ventilator. The second solenoid opened the circuit to the negative pressure box, allowing forced deflation. The third solenoid opened the circuit to atmospheric pressure, allowing relaxed deflation.

The forced deflation (FD) technique allows the examination of maximal expiratory maneuvers in subjects unable to perform a voluntary forced exhalation (14). This method standardizes for volume by inflating the lungs to total lung capacity (TLC). The intubated airway was then rapidly deflated to residual volume (RV) by the generation of a negative pressure gradient. Flows obtained at the various airway opening pressures were compared according to Fry et al. (15), at isovolume points of 50,25 , and $10 \%$ of forced vital capacity (MEF50\%, MEF $25 \%$, and MEF10\%, respectively). The maximal expired volume obtained from the FD maneuver was termed the FVC, and served as the reference volume for the calculation and comparison of flow rates at isovolume points. The curves were anchored at RV. Passive airway occlusion was also performed. It was assumed that with complete respiratory muscle paralysis there would be equilibrium of the pressure throughout the airways, and that airway opening reflected the elastic recoil pressure of the respiratory system. Pressure was measured during the occlusion, and the resultant flow-volume relationship $\left(\mathrm{t}_{\mathrm{rs}}\right)$ 
during passive expiration was examined. Extrapolation of the flowvolume profile to zero flow allowed the estimation of the total volume that would be exhaled, if the mouse emptied to the elastic equilibrium volume $(\mathrm{EEV})$ of the respiratory system. Compliance $\left(\mathrm{C}_{\mathrm{rs}}\right)$ was calculated from the ratio of the volume above EEV at which the occlusion was made, to the end-inspiratory recoil pressure at this volume. Resistance $\left(R_{r s}\right)$ was calculated by relating the time constant $\left(t_{r s}\right)$ to the measured compliance $\left(\mathrm{R}_{\mathrm{rs}}=\mathrm{t}_{\mathrm{rs}} / \mathrm{C}_{\mathrm{rs}}\right)$, assuming a linear relationship over the expired volume range. Airway occlusions were performed at the inflated lung volume of TLC. This was achieved by increasing the flow through the ventilator to give a ventilator pressure of $40 \mathrm{~cm} \mathrm{H} \mathrm{H}_{2} \mathrm{O}$, and an airway pressure of $18 \pm 0.2 \mathrm{~cm} \mathrm{H}_{2} \mathrm{O}$ (mean \pm SEM). TLC was sustained for $3 \mathrm{~s}$ before the occlusion of the airway and relaxed deflation to atmospheric pressure, or the application of a forced deflation. Airway opening pressures were initially zero (airway open to atmospheric pressure), and then decreased from -6 to $-12 \mathrm{~cm} \mathrm{H}_{2} \mathrm{O}$ at intervals of $-2 \mathrm{~cm} \mathrm{H}_{2} \mathrm{O}$. Maximal flows through endotracheal tubes alone were measured for the various deflation pressures. The resistance of the circuit was found to be flow dependent, ranging from $2-5 \mathrm{~cm} \mathrm{H}_{2} \mathrm{O}^{-1 / \mathrm{m} / \mathrm{s}}$. A one-way ANOVA was used for group comparisons of weight, flow-volume, compliance, and resistance, with a significance level of $P<0.05$. The Student Newman Keul's adjustment was used to determine differences among groups.

Nasal potential difference measurements. Three groups of animals were compared. The groups consisted of age-matched C57BL/6J wild type $(n=27)$, C56BL/6J Cftr ${ }^{m 1 U N C} / C f t^{m 1 U N C}(n=11)$, and $C f t r^{m l U N C}$ mice of mixed genetic background $(n=7)$. Methods were adapted from the clinical use of this technique in CF patients (16). The mice were anesthetized as described above, and a cannula (PE10) containing Ringers lactate was inserted $0.5 \mathrm{~cm}$ into the right nares. Ringers lactate was continuously perfused through this cannula at a rate of $1 \mathrm{ml} / \mathrm{h}$, via a 50-ml syringe attached to an infusion pump. The syringe was connected to a calomel electrode in $3 \mathrm{M} \mathrm{KCl}$ solution, and via an agar bridge to a voltmeter and recorder. A subcutaneous needle positioned on the abdomen was connected via an agar bridge to a second calomel electrode, which served as the reference electrode. Experimental reagents and drugs were administered through a tube that formed a sleeve surrounding the nasal catheter, and which ended $0.5 \mathrm{~cm}$ from the catheter tip. All solutions were warmed to $37^{\circ} \mathrm{C}$ before use. A steady PD measurement was obtained within a few minutes, at which time Ringers lactate solution containing $100 \mu \mathrm{M}$ amiloride (Sigma Chemical Co., St. Louis, MO) was perfused through the sleeve cannula at $3 \mathrm{ml} / \mathrm{h}$, while the flow of Ringers lactate was slowed to $0.3 \mathrm{ml} / \mathrm{h}$. The response to amiloride was monitored for 3-5 min. After the amiloride perfusion, the solution was changed to a $\mathrm{Cl}^{-}$-free solution, in which $\mathrm{Cl}^{-}$had been replaced by gluconate, with amiloride to provide a driving force for apical $\mathrm{Cl}^{-}$ conductance. The perfusion with Ringers lactate was discontinued during this manipulation. Following this, the activity of the $\mathrm{Ca}^{2+}$-activated $\mathrm{Cl}^{-}$channel in the apical membrane was assessed by the addition of $100 \mu \mathrm{M}$ uridine triphosphate (UTP; Boehringer Mannheim, Laval, Quebec, Canada), an agonist of phospholipase $\mathrm{C}$ and $\mathrm{IP}_{3}$-mediated $\mathrm{Ca}^{2+}$ release from intracellular stores. Data were tabulated and expressed as mean \pm SEM.

\section{Results}

Disease severity in congenic mice. Fewer congenic $\mathrm{CF}$ mice (C57BL/6J Cftr ${ }^{m 1 U N C} / C f t r^{m l U N C}$ ) survived the perinatal period than did CF mice of a mixed genetic background $\left(C f t^{m 1 U N C}\right)$. Survival of UNC CF animals at $20 \mathrm{~d}$ was $15.5 \%$ (of all live births) in the outbred animals, and only $6.4 \%$ in the congenic C57BL/6J CF animals, indicating a more severe phenotype. Deaths were usually observed within $3 \mathrm{~d}$ of birth in both groups and, when autopsy was possible, the cause of death was intestinal disease. Both the colon and the distal ileum were involved.
Pathology-light microscopy. No abnormal histology was detected in the sinuses or tracheas or large bronchi of any animals (not shown). However, whole lung sections demonstrated marked and widespread pathology in the C57BL/6J CF lungs (Fig. 1, $E$ and $F$ ). Lesions were patchy, with areas of marked acinar dilatation consistent with obstructive small airway disease, and also areas of interstitial thickening. Interstitial disease could be detected as early as $30 \mathrm{~d}$ of age. In the C57BL/6J $\mathrm{CF}$ animals, there was an accumulation of inflammatory cells and connective tissue in the alveolar wall, resulting in alveolar wall thickening and loss of alveolar architecture even at this early age. These pathological changes did not represent an homogeneous process. Patchy areas of abnormality were scattered throughout the lungs. The pathological changes were more severe in older animals and, by three months, sections stained with Masson's trichrome revealed distinct areas of enhanced staining in the alveolar interstitium, which had further increased in intensity by 6 mo of age (not shown), indicative of an increased deposition of collagen and other fibrillar material. Positive staining with Periodic Acid-Schiff (PAS), for acidic mucopolysaccharides, was seen in material lining normal C57BL/6J and UNC CF airways (Fig. 1, $B$ and $D$ ). This was markedly increased in extent and intensity in the airways of C57BL/6J CF mice, and intracytoplasmic staining was also evident in nonciliated cells lining the airways (Fig. $1 F$ ).

Lung pathology; electron microscopy of the airways. Scanning electron microscopy of lungs from C57BL/6J CF mice 6 mo after birth showed many bronchiolar surfaces covered with a thick layer of a material (Fig. $2 E$ ), which was also evident in alveoli (Fig. $2 F$ ), but not in control C57BL/6J mice (Fig. 2, $A$ and $B$ ), or UNC CF mice (Fig. 2, $C$ and $D$ ). Morphometric analysis revealed clear differences in airway epithelial cell composition between controls and C57BL/6J CF mice (Table I). The C57BL/6J CF mice had an age-dependent increase in the relative proportion of nonciliated cells, which were assumed to be secretory cells. At $1 \mathrm{mo}, \mathrm{C} 57 \mathrm{BL} / 6 \mathrm{~J} \mathrm{CF}$ mice had proportionally less nonciliated cells than did animals in either control group $(P<0.01)$. The 3 - and $6-\mathrm{mo}$ C57BL/6J CF mice had a significant increase $(P<0.005)$ in the proportion of nonciliated airway cells (56-60\%) compared with control animals (37-42\%). Nonciliated cell morphology also differed between the three groups of animals (Fig. 3, $A-C$ ). In the 1-mo C57BL/ $6 \mathrm{~J} \mathrm{CF}$ mice, the majority of the nonciliated cells contained few if any secretory granules, few mitochondria and only occasional osmiophilic droplets adjacent to the apical membrane. By 3 mo of age, the most striking change in the nonciliated cell cytoplasm of affected animals was a proliferation of smooth endoplasmic reticulum, as well as an increase in the number of secretory granules. By $6 \mathrm{mo}$, the nonciliated cell cytoplasm contained numerous secretory granules, with lipid-like material sequestered in the smooth endoplasmic reticulum. This was in marked contrast to $\mathrm{C} 57 \mathrm{BL} / 6 \mathrm{~J}$ control animal nonciliated cell morphology, in which secretory granules were frequent at $1 \mathrm{mo}$, and neither proliferation nor sequestration of material within the smooth endoplasmic reticulum occurred in older C57BL/6J control animals. The findings in UNC CF mice (not shown) were not different from C57BL/6J control animals.

Lung pathology; electron microscopy of the alveolar region. Compared with C57BL/6J control mice (Fig. $4 A$ ), the interalveolar interstitium of the $\mathrm{C} 57 \mathrm{BL} / 6 \mathrm{~J}$ CF mice contained an increase in fibroblasts containing lipid-like material by $6 \mathrm{mo}$ 

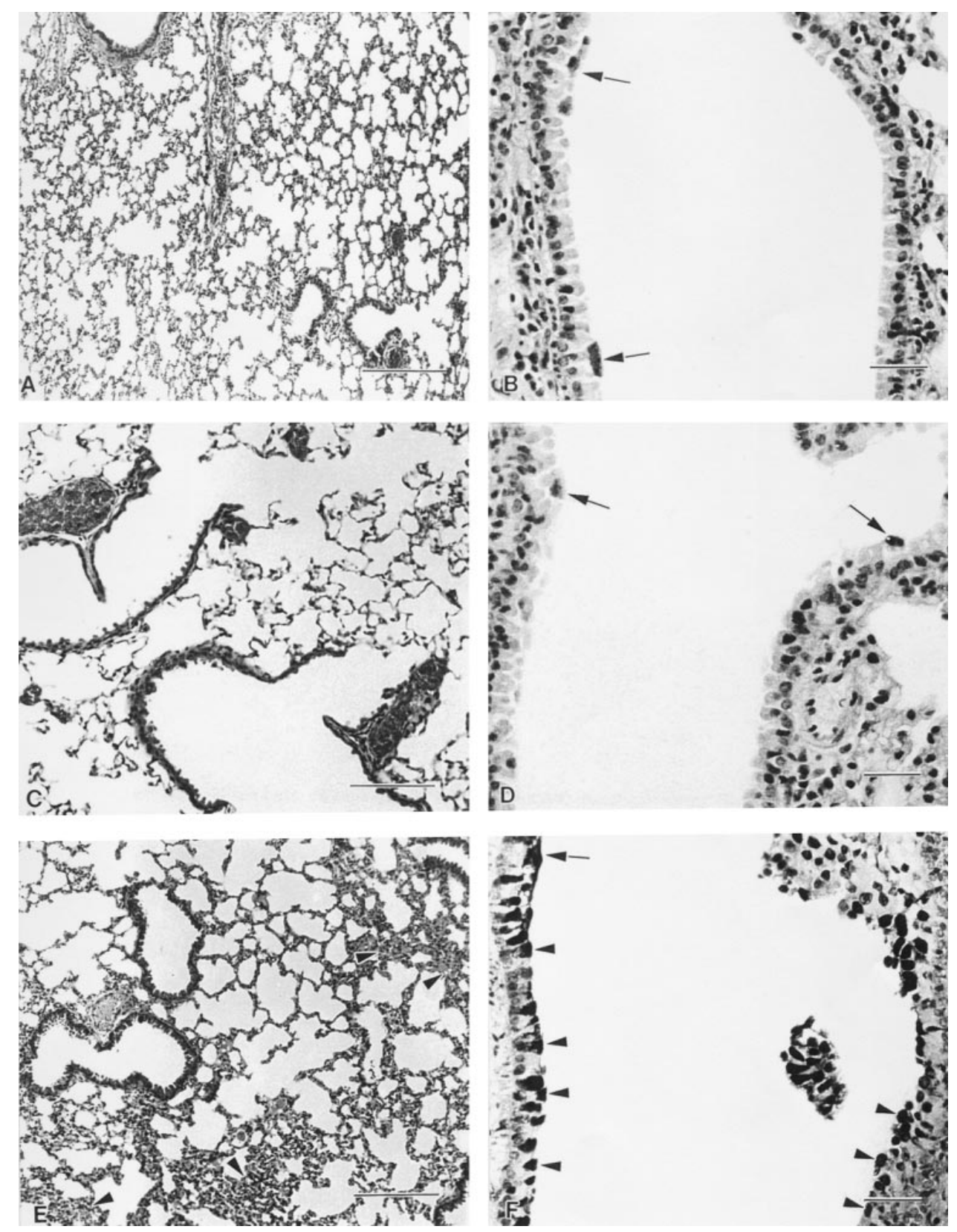

Figure 1. Lung morphology. (A) Low power view of control C57BL/ $6 \mathrm{~J}$ lung at six months. Bar $=0.25$ mm. (C) Low power view of control $C f t r^{m I U N C}$ lung at $6 \mathrm{mo}$, showing normal architecture. $\mathrm{Bar}=0.25$ $\mathrm{mm}$. (E) Low power view of $6 \mathrm{mo}$ C57BL/6J Cftr ${ }^{m 1 U N C} / C \mathrm{ftr}^{\mathrm{ml} I N C}$ lung showing enlarged acini and areas of interstitial thickening (arrowheads). Bar $=0.25 \mathrm{~mm}$. Staining with PAS to show material consistent with acid mucopolysaccharide on the airway surface (arrows) and in secretory cells (arrowheads) of control C57BL/6J (B), CftrmlUNC $(D)$ and C57BL/6J $C f t r^{m l U N C} / C f t r^{m l U N C}(F)$ lungs at $6 \mathrm{mo}$. Bars, $24 \mu \mathrm{m}$.

of age, and the increased deposition of fibrillar material suggested by light microscopy was clearly seen on transmission electron microscopy (Fig. $4 \mathrm{~B}$ ). The fibroblastic nature of the cells containing the lipid-like material was confirmed using antibodies to a mesenchymal cell-specific cytoskeletal protein, vimentin (not shown). The interalveolar interstitium of the UNC CF mice (not shown) was no different to that of the C57BL/6J $\mathrm{CF}$ mice. Morphometric analysis of interalveolar interstitial areas of C57BL/6J CF mice (Table I) demonstrated a significant increase in granulocytes at $1 \mathrm{mo}$ of age $(P<0.005)$. Granulocyte numbers remained above control values at 3 and 6 mo, but were not statistically significant. There was also a significant increase $(P<0.005)$ in interstitial macrophages and fibroblasts by 3 mo of age, with a significant increase $(P<0.005)$ still present at 6 mo (Table I) in C57BL/6J CF mice. Control animals had an increase in interstitial fibroblasts with age, but this was of a lesser degree than in C57BL/6 J CF mice. C57BL/6J
CF mice had type I pneumocytes with apparently normal morphology, in contrast to their type II pneumocytes which were clearly abnormal (Fig. 4 C). The type II pneumocytes in C57BL/6J CF mice had an increased number of mitochondria and fewer surfactant-containing lamellar bodies, which was most evident in older animals.

Bacterial colonization. No viral, mycoplasmal, fungal, or other respiratory pathogens were identified in any of the 50 animals tested by serology. Histological examination of those control animals sharing housing space with the colony of $\mathrm{CF}$ mice, revealed no pathological lesions in any of the organs examined. Lung cultures of the CF mice showed no growth of Pseudomonas, Burkholderia, or Haemophilus species or of coagulase-positive Staphylococcus aureus, the organisms most commonly associated with human CF lung disease. A scant growth of non-pathogenic Streptococcus viridans was found in the lungs of three of the five CF mice undergoing autopsy, but 

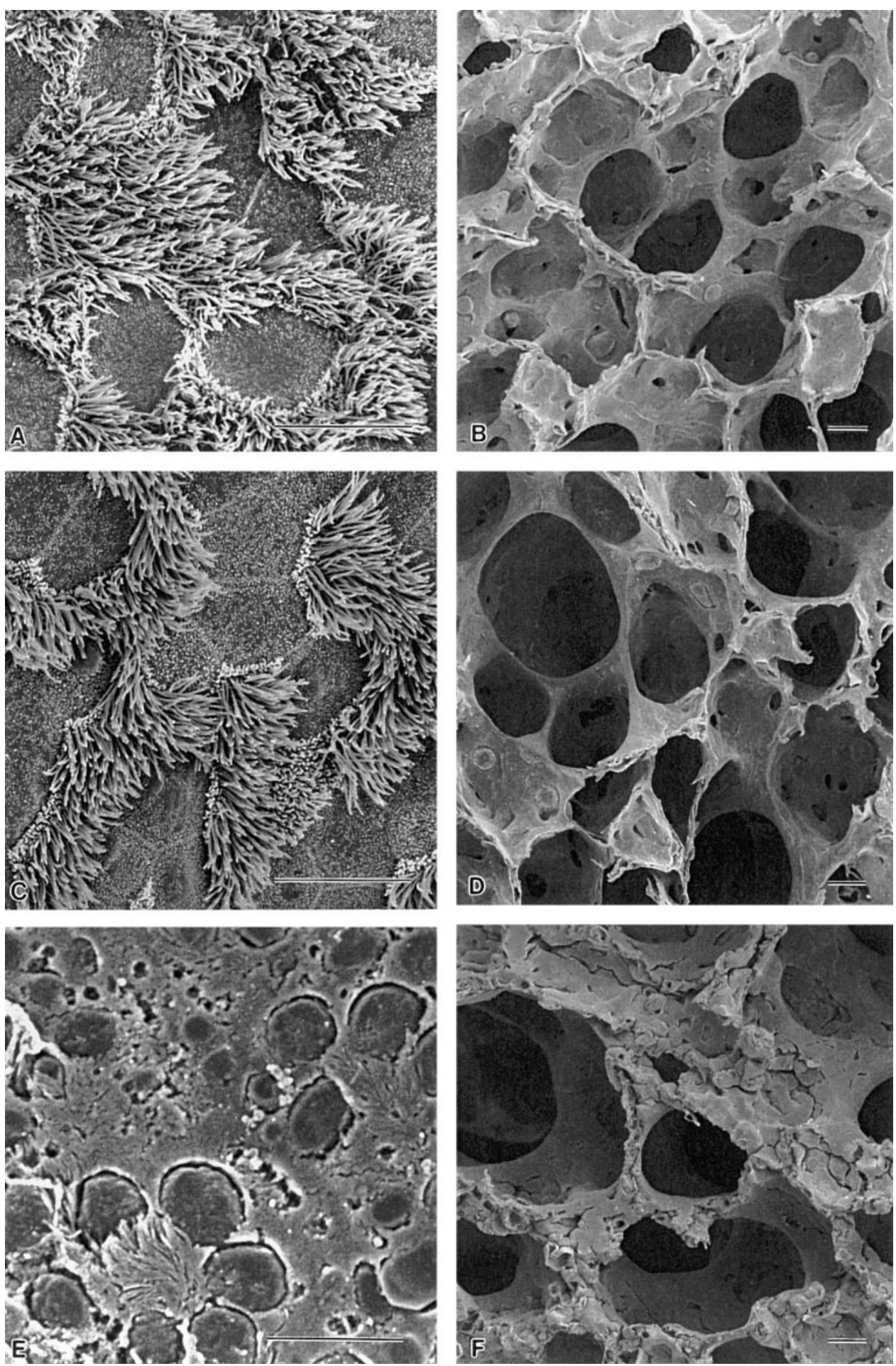

Figure 2. Scanning electron microscopy. Micrographs of control C57BL/6J ( $A$ and $B), C f t r^{m I U N C}(C$ and $D)$ and $C 57 \mathrm{BL} / 6 \mathrm{~J} C f t^{m i U N C /}$ $C f t^{m I U N C}(E$ and $F)$ lungs at 6 mo to show the airway epithelial surface $(A, C$, and $E)$ and alveoli $(B, D$, and $F)$. In the lungs from $C f t r^{m I U N C /}$ $C f t^{m I U N C}$ mice, a thick layer of material is seen covering the airway epithelium $(E)$, which extends to the alveoli $(F)$. Bars, $10 \mu \mathrm{m}$.

these animals did not demonstrate any more severe lung pathology. No organisms were isolated from the lungs of the control animals.

Pulmonary function tests. Although total respiratory system compliance and resistance have been measured in mice, such global measurements of lung function may be too insensitive to detect early small airway pathology (17-19). In an attempt to enhance the sensitivity of testing in mice, we adapted two methods used to detect small airway disease in infants (20): the single breath passive occlusion, and the forced nega- tive pressure deflation techniques $(14,20,21)$. The C57BL/6J CF mice were significantly $(P<0.05)$ growth restricted $(21.74 \pm 2.34 \mathrm{~g}$; mean \pm SEM) relative to their age-matched controls $(33.98 \pm 4.86 \mathrm{~g}$; mean \pm SEM). UNC CF mice had intermediate weights $(27.28 \pm 2.99 \mathrm{~g}$; mean \pm SEM $)$. Therefore, to correct for these size differences, we corrected lung mechanics measurements, when appropriate, by dividing by body weight. The respiratory system compliance, per kilogram body weight, was significantly greater in the $\mathrm{C} 57 \mathrm{BL} / 6 \mathrm{~J}$ CF mice $(P<0.05)$ than in either control groups (Fig. $5 A$ ). The forced vital capac- 

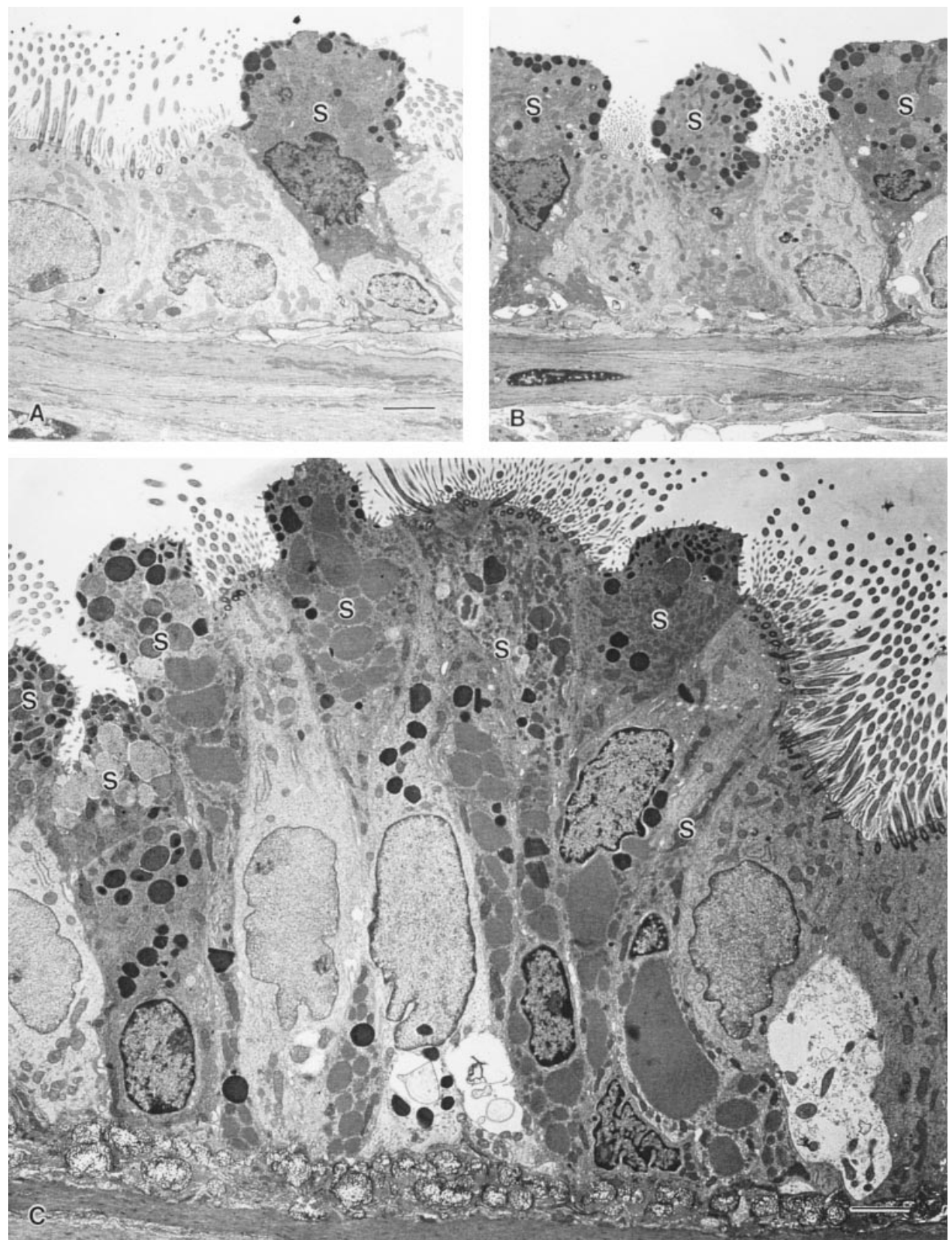

Figure 3. Transmission electron microscopy. Micrographs of airway nonciliated cells in control C57BL/ $6 \mathrm{~J}$ lung at $6 \mathrm{mo}(A)$, or $\mathrm{C} 57 \mathrm{BL} / 6 \mathrm{~J}$ $C \operatorname{ftr}^{\mathrm{ml} U N C} / C f \mathrm{fr}^{\mathrm{ml} I U N C}$ lungs at $3(B)$ and $6(C)$ mo to show the relative increase in the nonciliated cell population. All bars, $1 \mu \mathrm{m}$. ity (FVC), a measure of lung volume, was significantly $(P<$ $0.05)$ less, per kilogram body weight, in the UNC CF mice compared with $\mathrm{C} 57 \mathrm{BL} / 6 \mathrm{~J}$ control of $\mathrm{CF}$ mice (Fig. $5 \mathrm{~B}$ ). The mean FVC was increased $\sim 20 \%$ in $\mathrm{C} 57 \mathrm{BL} / 6 \mathrm{~J}$ CF mice compared with C57BL/6J control animals, consistent with air trapping, but this did not achieve statistical significance. There was no significant difference for respiratory system resistance (Fig. $5 \mathrm{C}$ ). Because airway resistance declines with increased size, this parameter was not corrected for weight. Respiratory system resistance is a measurement dominated by the resistance of the large airways. In an attempt to assess the condition of the peripheral airways, we measured the maximum expiratory flow at 50, 25 and 10\% of the FVC. Though there was an apparent trend towards a reduction in flows at 25 and $10 \%$ of the FVC in C57BL/6J CF and UNC CF animals compared with C57BL/6J control animals, consistent with narrower peripheral airways, statistical significance was not achieved.
Nasal potential difference. To determine whether there may be differences in respiratory epithelial ion transport associated with the development of airway disease in these $C f t^{m l U N C /}$ $C f t r^{m 1 U N C}$ animals, the bioelectrical properties of their nasal mucosa were compared with measurements obtained in either their non-CF siblings or $C f t r^{m l U N C}$ mice, neither of which had lung disease. Typical nasal PD profiles of wild-type and congenic $\mathrm{CF}$ animals are shown in Fig. $6 \mathrm{~A}$, and aggregate data in Fig. $6 \mathrm{~B}$. The congenic $\mathrm{CF}$ mice exhibited a significantly elevated negative basal $P D$ profile, when compared with the wild type $(P<0.002)$, and lacked the normal PD response to the imposition of a luminally directed $\mathrm{Cl}^{-}$gradient when exposed to a $\mathrm{Cl}^{-}$-free solution $(P<0.05)$. This feature is consistent with the absence of a $\mathrm{Cl}^{-}$conductance, namely CFTR, from the apical surface of the nasal epithelium (22). Surprisingly, there was no significant difference in the drop in PD in response to amiloride between the wild type and the congenic CF mice. In 
Table I. Morphometric Analyses of Lungs from Control C57BL/6J, Cftr ${ }^{m I U N C}$ and C57BL/6J Cftr ${ }^{m I U N C} / C f t r^{m I U N C}$ mice

\begin{tabular}{|c|c|c|c|c|c|}
\hline \multicolumn{6}{|c|}{ Percent nonciliated cells in bronchiole } \\
\hline \multicolumn{2}{|c|}{ C57BL/6J } & \multicolumn{2}{|c|}{$C f t r^{m I U N C}$} & \multicolumn{2}{|c|}{$\begin{array}{c}\text { C57BL/6J } \\
C f t r^{m l U N C} / C f t r^{m l U N C}\end{array}$} \\
\hline $1 \mathrm{mo}$ & $45.4 \pm 8.2$ & $1 \mathrm{mo}$ & $43.8 \pm 10.2$ & $1 \mathrm{mo}$ & $33.0 \pm 9.3$ \\
\hline $3 \mathrm{mo}$ & $40.6 \pm 8.2$ & $3 \mathrm{mo}$ & $40.7 \pm 9.9$ & $3 \mathrm{mo}$ & $56.6 \pm 10.8$ \\
\hline $6 \mathrm{mo}$ & $37.7 \pm 5.9$ & $6 \mathrm{mo}$ & $41.2 \pm 8.3$ & $6 \mathrm{mo}$ & $60.3 \pm 8.9$ \\
\hline \multicolumn{6}{|c|}{ Interstitial macrophages $/ \mathrm{mm}^{2}$} \\
\hline \multicolumn{2}{|c|}{$\mathrm{C} 57 \mathrm{BL} / 6 \mathrm{~J}$} & \multicolumn{2}{|c|}{$C f t r^{m l U N C}$} & \multicolumn{2}{|c|}{$\begin{array}{l}\text { C57BL/6J } \\
C f t r^{m I U N C / C f t r^{m l U N C}}\end{array}$} \\
\hline $1 \mathrm{mo}$ & $4.1 \pm 1.3$ & $1 \mathrm{mo}$ & $4.9 \pm 1.3$ & $1 \mathrm{mo}$ & $3.7 \pm 0.6$ \\
\hline $3 \mathrm{mo}$ & $4.3 \pm 0.7$ & $3 \mathrm{mo}$ & $4.6 \pm 2.0$ & $3 \mathrm{mo}$ & $18.0 \pm 4.3$ \\
\hline $6 \mathrm{mo}$ & $5.3 \pm 1.2$ & $6 \mathrm{mo}$ & $4.8 \pm 1.6$ & $6 \mathrm{mo}$ & $21.3 \pm 3.1$ \\
\hline & & \multicolumn{4}{|c|}{ Interstitial fibroblasts $/ \mathrm{mm}^{2}$} \\
\hline \multicolumn{2}{|c|}{ C57BL/6J } & \multicolumn{2}{|c|}{ CftrmlUNC } & \multicolumn{2}{|c|}{$\begin{array}{c}\text { C57BL/6J } \\
C f t^{m I U N C} / C f t r^{m l U N C}\end{array}$} \\
\hline $1 \mathrm{mo}$ & $6.2 \pm 1.8$ & $1 \mathrm{mo}$ & $6.0 \pm 2.2$ & $1 \mathrm{mo}$ & $6.4 \pm 1.4$ \\
\hline $3 \mathrm{mo}$ & $10.3 \pm 4.2$ & $3 \mathrm{mo}$ & $9.4 \pm 2.8$ & $3 \mathrm{mo}$ & $31.7 \pm 5.1$ \\
\hline $6 \mathrm{mo}$ & $19.7 \pm 5.2$ & $6 \mathrm{mo}$ & $21.2 \pm 6.9$ & $6 \mathrm{mo}$ & $79.0 \pm 8.7$ \\
\hline \multicolumn{6}{|c|}{ Granulocytes $/ \mathrm{mm}^{2}$} \\
\hline \multicolumn{2}{|c|}{$\mathrm{C} 57 \mathrm{BL} / 6 \mathrm{~J}$} & \multicolumn{2}{|c|}{ CftrmlUNC } & \multicolumn{2}{|c|}{$\begin{array}{c}\text { C57BL/6J } \\
C f t r^{m I U N C / C f t r^{m l U N C}}\end{array}$} \\
\hline $1 \mathrm{mo}$ & $3.1 \pm 1.1$ & $1 \mathrm{mo}$ & $3.5 \pm 1.4$ & $1 \mathrm{mo}$ & $14.2 \pm 2.9$ \\
\hline $3 \mathrm{mo}$ & $2.8 \pm 0.8$ & $3 \mathrm{mo}$ & $3.3 \pm 1.8$ & $3 \mathrm{mo}$ & $8.9 \pm 1.6$ \\
\hline $6 \mathrm{mo}$ & $3.7 \pm 0.6$ & $6 \mathrm{mo}$ & $4.0 \pm 1.6$ & $6 \mathrm{mo}$ & $8.1 \pm 2.4$ \\
\hline
\end{tabular}

previous studies with mice and humans, it had been found that the elevated basal PD characteristic of CF epithelia was accounted for by the augmentation of an amiloride-sensitive sodium conductance (24). We suggest that the elevated negative basal PD seen in the C57BL/6J Cftr ${ }^{m 1 U N C} / C f t r^{m 1 U N C}$ mice may be due to the activity of apical sodium transport pathways that are not amiloride-inhibitable, as has been previously described in bovine tracheal epithelium (23). Furthermore, C57BL/6J wild type and C57BL/6J Cftr ${ }^{m 1 U N C} / C f t^{m 1 U N C}$ mice failed to show a $\mathrm{PD}$ response to the administration of UTP, an agonist of $\mathrm{P}_{2 \mathrm{U}}$ type purinergic receptors, coupled to $\mathrm{IP}_{3}$-mediated $\mathrm{Ca}^{2+}$ release from intracellular stores. These results contrast with those seen in the $C f t r^{m 1 U N C} / C f t r^{m 1 U N C}$ mice, in which UTP evoked a large change in nasal PD in the present and previously published (24) studies, a response thought to represent stimulation of apically localized $\mathrm{Ca}^{2+}$-activated $\mathrm{Cl}^{-}$channels. Hence, our results suggest that the $\mathrm{C} 57 \mathrm{BL} / 6 \mathrm{~J}$ mice either lack this conductance path, or that it can not be activated properly. Alternatively, it is conceivable that the inability to detect a change in negative PD with UTP is secondary to the persistence of a basally-active, amiloride-insensitive $\mathrm{Na}^{+}$absorptive path.

\section{Discussion}

For technical reasons, the production of knockout mice is limited to the strain from which the embryonic stem cell lines are derived, and subsequent breeding frequently involves the use of mice of different strains to increase viability. Unfortunately, the resulting progeny carry a mixed genetic background that may vary both over time and between breeding colonies. It is clear, from this study and previously published (10) studies, that disease severity in CF is genetically determined by additional modifier loci. As in humans with $\mathrm{CF}, \mathrm{C} 57 \mathrm{BL} / 6 \mathrm{~J}$ $C f t r^{m 1 U N C} / C f t r^{m 1 U N C}$ mice develop severe peripheral lung injury. As significant macroscopic and microscopic structural differences exist between normal mouse and human lungs, some differences in pathology of mouse and human CF lung disease must be expected on these grounds alone. Humans and laboratory mice with $\mathrm{CF}$ are also exposed to very different environments. In the human, the characteristic airway changes are of epithelial metaplasia, inflammatory infiltrate, bronchiectasis, and mucopurulent plugging $(25,26)$. Given the high incidence of acute and chronic infections in the human population, it is difficult to know the degree to which these changes are secondary to infection, or how similar the morphology of the human airway would be to that seen in the mouse in the apparent absence of severe respiratory pathogens. Despite these reservations, human and mouse $\mathrm{CF}$ lungs do share a number of characteristics.

Histological changes in CF mouse lungs were consistently observed, and were obvious even in the lungs of animals as young as $30 \mathrm{~d}$. Low power views, using light microscopy, showed that the congenic animals develop acinar and alveolar hyperinflation consistent with obstructive small airway disease, which is a characteristic and early feature of human $\mathrm{CF}$ $(25,26)$. In young human patients with $\mathrm{CF}$, pulmonary function testing has shown small airway disease to be present even before there is any evidence of acinar hyperinflation (7). This hyperinflation in the mouse may, as in the human (25), be attributable to a failure of mucociliary transport, with a build up of material with characteristics of an acid mucopolysaccharide in the distal airways, causing a ball valve obstruction. That a similar pattern of obstruction occurs in the CF mouse lung was suggested by our scanning EM observations. Despite attempts to increase the sensitivity of pulmonary function tests for assessment of distal airways, inherent limitations of methodology did not allow us to confirm flow limitation in distal airways. The observed increase in static compliance (reduced recoil) of the $\mathrm{CF}$ mouse lungs is also consistent with the increase in weight-corrected FVC and the histological changes, and is seen in other situations in which there is over distension of acini (27).

The material accumulating in the airways of $\mathrm{CF}$ mice has the characteristics of an acid mucopolysaccharide, in that it stains with PAS $(12,13)$. As yet, we do not have sufficient information to identify which cell type is the source of this material. PAS-positive material is found in the matrix immediately adjacent to nonciliated cells in normal lungs of several species, and not within the cell (28). In the CF mouse lung, cells containing PAS-positive material were found in nonciliated airway epithelial cells. Whether this represents an adaptation of the normal resident nonciliated (Clara) cell population, or the appearance of cells with a different lineage, can not be determined from the studies presented here. The Clara cell arises from differentiation of fetal glycoprotein-secreting cells, as do mucus-secreting cells (29), which is of potential relevance given the recent suggestion that CFTR may play a regulatory role in the development of secretory airway cells (30).

Foci of fibrosis are seen at autopsy of human patients with $\mathrm{CF}$, as was also seen in the congenic CF mice $(12,13)$. The parenchymal interstitial disease is, however, an early and rela- 

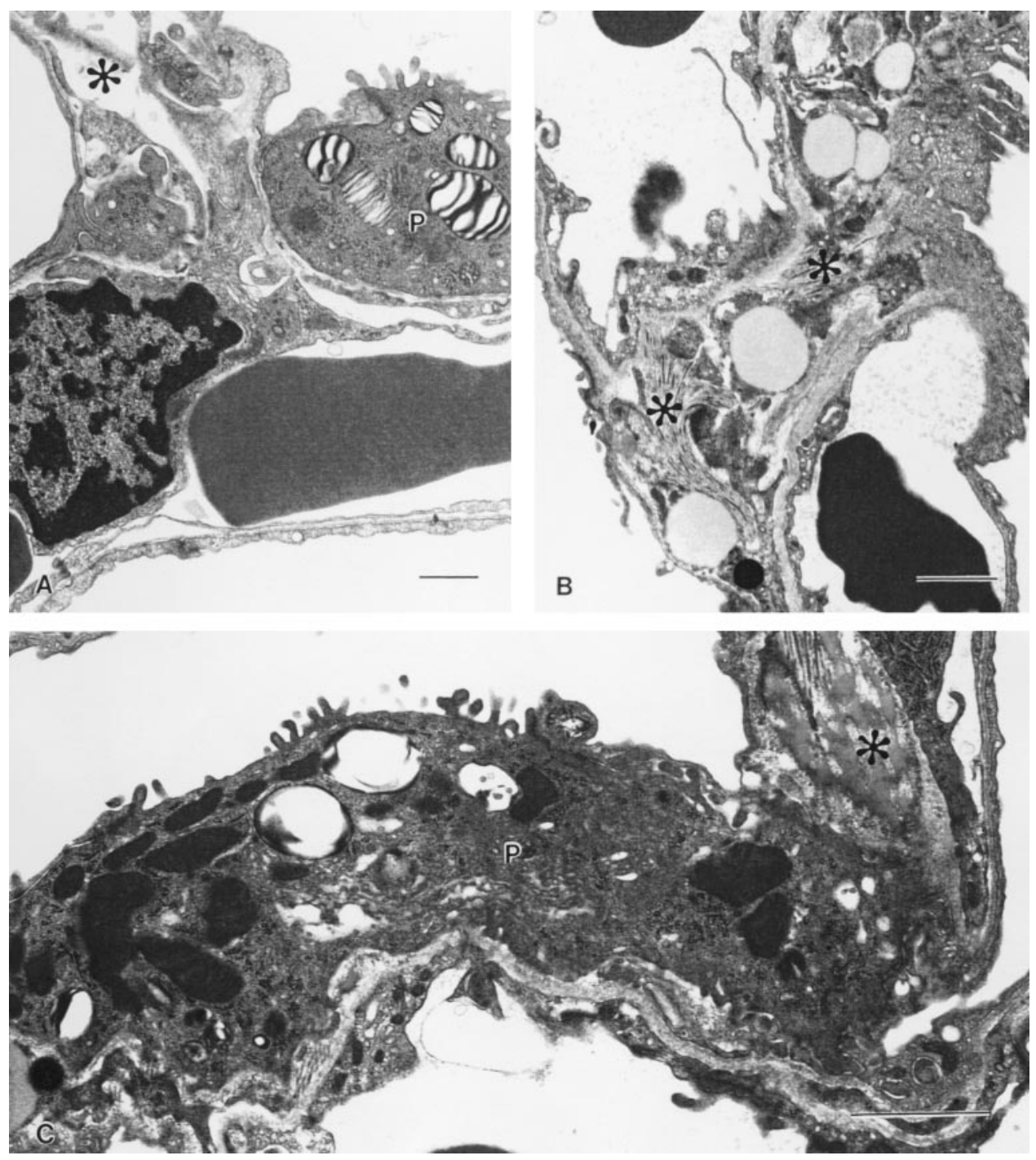

Figure 4. Characteristics of lung interstitium. Interstitial areas $(*)$ of control C57BL/6J $(A)$ or C57BL/6J $C f t^{m I U N C} / C f t^{m I U N C}$ lungs $(B$ and $C$ ) at 6 mo. In the C57BL/6 J CftrmlUNC/ $C f t^{m I U N C}$ lungs, there are fibroblasts containing large lipid-ladened vacuoles, and a marked increase in fibrillar matrix protein $(B)$. Type II pneumocytes $(P)$ also had a markedly abnormal appearance in the C57BL/6J Cftr ${ }^{m I U N C} / C$ tr $^{m 1 U N C}$ lungs (C). Bars are $0.5 \mu \mathrm{m}(A$ and $B)$ or 1 $\mu \mathrm{m}(C)$.
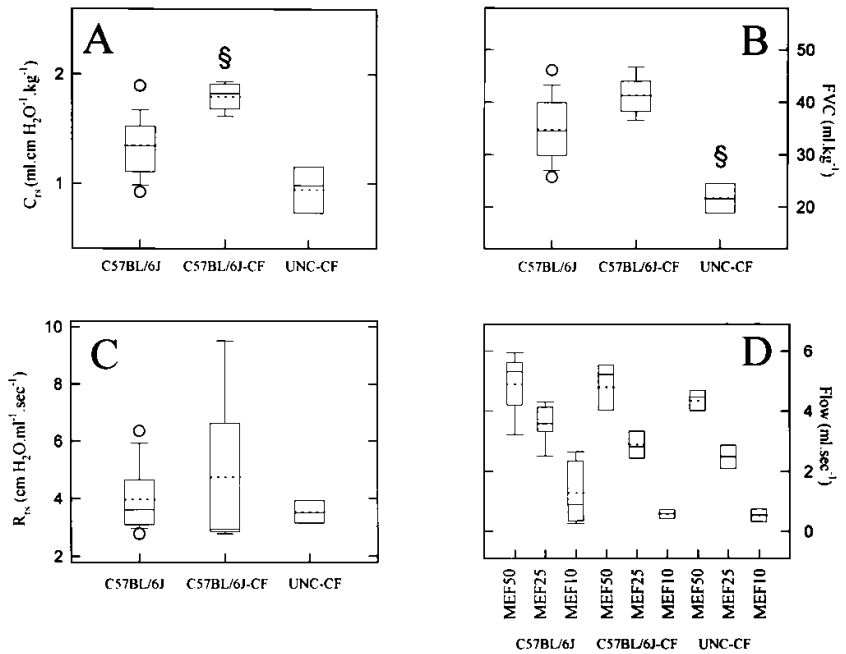

Figure 5. Pulmonary function tests of C57BL/6J, C57BL/6J $C f t r^{m 1 U N C} / C f t r^{m 1 U N C}$ (C57BL/6J-CF) and $C f t r^{m 1 U N C} / C f t r^{m 1 U N C}$ (UNC$C F)$ mice. Box plots of $(A)$ weight-corrected total respiratory system compliance $\left(C_{r s}\right) ;(B)$ weight-corrected forced vital capacity $(F V C)$; $(C)$ total respiratory system resistance $\left(R_{r s}\right)$ and $(D)$ expiratory flow tively larger component of the lung disease in the congenic $\mathrm{CF}$ mouse lung than in the human. A degree of inflammatory cell influx into the lungs of humans with CF is now recognized as an early process, from the results of recent clinical studies of bronchiolar lavage fluid samples from very young children with $\mathrm{CF}(5,6)$. The young congenic $\mathrm{CF}$ mice also had increased granulocyctes, as well as fibroblast infiltration and deposition of fibrillar matrix proteins into the interstitium by $21 \mathrm{~d}$ of age. Phenotypic differences in pulmonary interstitial fibroblast populations, distinguishable by their lectin-binding characteristics, may be critical determinants of lung growth and lung injury $(31,32)$. Lipid-containing fibroblasts, as seen in the lungs of the congenic $\mathrm{CF}$ mice, have been reported by others to be Thy 1 positive, and to secrete more collagen than fibronectin, in contrast to a Thy 1 negative population that secretes more

measurements at airway opening pressures of $-8 \mathrm{~cm} \mathrm{H}_{2} \mathrm{O}$. Upper and lower boundaries of the box represent the $75^{\text {th }}$ and $25^{\text {th }}$ percentiles, respectively, with the upper and lower error bars representing the $90^{\text {th }}$ and $10^{\text {th }}$ percentiles, respectively. Within the box the solid line represents the median, while the interrupted line represents the mean. Outlying points are shown as open circles. $\S=P<0.05$. 


\section{A}

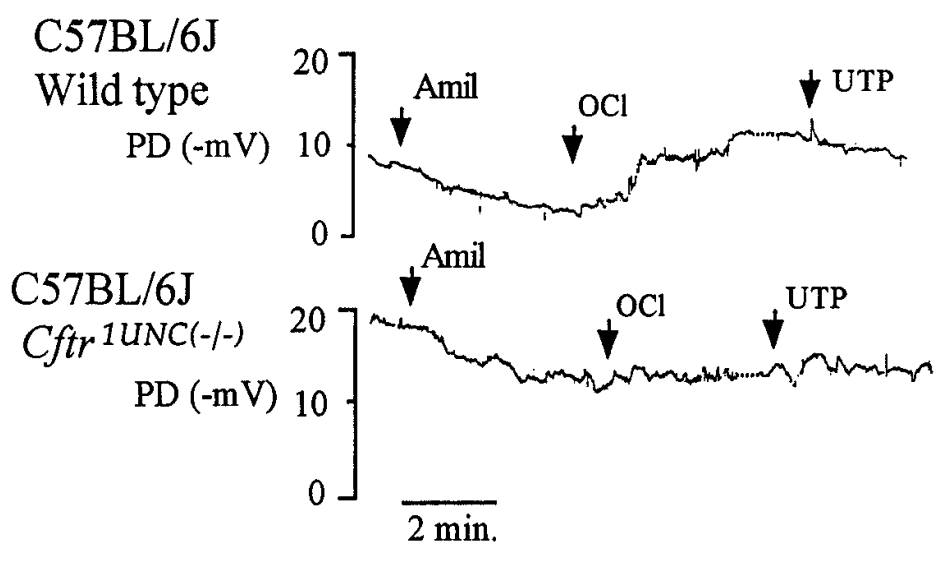

B

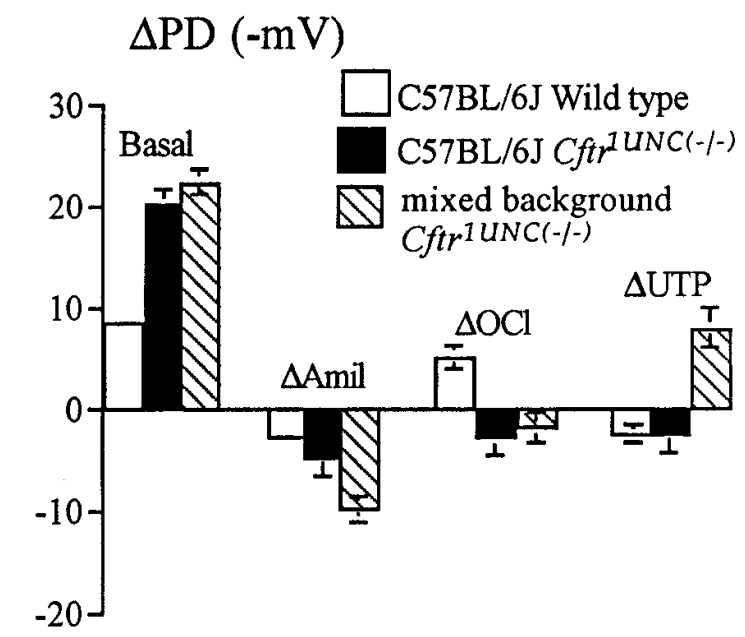

Figure 6. Measurements of nasal PD. Representative nasal PD tracings $(A)$ in wild-type C57BL/6J and C56BL/6J $C f t r^{m 1 U N C} / C f t r^{m 1 U N C}$ mice. $A m i l$, addition of $100 \mu \mathrm{M}$ amiloride; $O C l$, elimination of luminal $\mathrm{Cl}^{-}$; and $U T P$, addition of $100 \mu \mathrm{M} \mathrm{UTP}$. Summary data are shown as mean \pm SEM for 27 wild-type C57BL/6J mice, 11 C57BL/6J Cftr ${ }^{m l U N C} / C f t r^{m l U N C}$ mice, and $7 C f t^{m 1 U N C / C f t r^{m l U N C}}$ mice $(B)$. The C57BL/6J $C f t^{m I U N C} / C f t^{m I U N C}$ mice have a significantly elevated basal PD relative to wild-type C57BL/6J mice $(P<0.002)$. The $\mathrm{PD}$ response to a Cl- ${ }^{-}$free solution of C57BL/6J $C f t^{m I U N C(--)}$ mice was significantly reduced compared with wild-type C57BL/6J mice $(P<0.05)$. Both the C57BL/6J

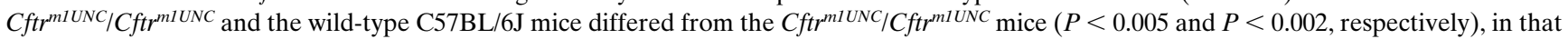
they failed to exhibit a response to treatment with UTP.

fibronectin than collagen (33). This is consistent with the finding of increased lipid-containing fibroblasts in regions with increased fibrillar matrix protein deposition. Type II pneumocyte injury, as seen in the congenic CF model, is not a characteristic feature of human $\mathrm{CF}$ lung disease.

The failure of the $C f t r^{\text {mIUNC }}$ mice, of mixed genetic background, to develop lung disease has been attributed to the vigorous activity of alternate $\mathrm{Cl}^{-}$channels in their airway epithelium (26). In the present study, we observed the ion transport properties of the nasal epithelium of C57BL/6 mice to be different from those previously reported for $C f t r^{m 1 U N C} / C f t r^{m l U N C}$ mice. The purinergic receptor agonist, UTP, failed to activate a change in PD in the C57BL/6J Cftr ${ }^{m 1 U N C} / C f t r^{m 1 U N C}$ mice in contrast to the results observed with the $C f t^{m 1 U N C} / C f t r^{m l U N C}$ mice (34). This supports the hypothesis that the severely affected C57BL/6J Cftr ${ }^{m 1 U N C} / C f t r^{m l U N C}$ mice lack, or fail to activate, an alternative $\mathrm{Cl}^{-}$conductance path. Hence, we speculate that the combination of an heritable absence of an UTP-activated $\mathrm{Cl}^{-}$channel with an experimentally engineered lack of CFTR could account for the development of lung disease in the congenic CFTR-knockout mice. Clearly, this speculation is predicated on the assumption that the ion transport pathways monitored in the nasal epithelium are representative of ion transport events occurring in the lower airways. The relationship between this loss of $\mathrm{Cl}^{-}$conductance and the development of lung disease has not been addressed in this study, but others have postulated that the $\mathrm{Cl}^{-}$ion plays a role in the bactericidal capacity of the surface fluid bathing the airway epithelium, as well as in the rheology of its mucus layer (35). Alternatively, there may be a variation in the nature or properties of the $\mathrm{Na}^{+}$channels which mediate absorption across the airway epithelia of C57BL/6J mice. Our results indicate that there may be $\mathrm{Na}^{+}$channels (36) other than the typical amilo- ride-sensitive epithelial $\mathrm{Na}^{+}$channel $(\mathrm{ENaC})$, which predominate in these mice to cause a high negative nasal PD. Clearly, the activity of these channels may modulate the composition of the fluid bathing the airway epithelium of the C57BL/6J $C f t^{m 1 U N C} / C f r^{m 1 U N C}$ mice.

There is a widely held, though still contentious, view that bacterial colonization with unusual organisms, particularly with Pseudomonas aeruginosa, of the airways of CF patients results in the development of significant lung disease. The observation that children under 6 mo of age, several of whom demonstrated no evidence of bacterial colonization, had an increase in polymorphonuclear cell count and increased free elastase activity in their bronchoalveolar lavage fluid calls an obligatory role for infection into question (2). The congenic CF mouse model also developed a progressive inflammatory disease with no pathogenic organisms having been detected. It is never possible to completely exclude the presence of pathogenic infectious agents, despite repeatedly negative cultures and serology, and we can not absolutely exclude an etiological role for some undetected pathogen. However, it will still be of future interest to challenge the congenic CF mice with respiratory pathogens, to determine if the morphologic changes seen in their lungs, particularly the airway epithelium, are modified to a pattern more consistent with human disease.

While there are some pathological differences in the $\mathrm{CF}$ lung diseases of mice and humans, we anticipate that the congenic CF mouse will prove to be a valuable tool with which to address some of the outstanding questions related to the pathophysiology of CF. It will, perhaps, prove most valuable for studies of gene or protein therapeutic interventions, in which efficacy of intervention could not previously be determined in conventional models because of the absence of lung disease. The major practical limitation of this animal model is 
the severity of their gastrointestinal disease, which severely limits the survival of congenic CF mice and the numbers of animals available for study.

\section{Acknowledgments}

We gratefully acknowledge the technical assistance of S. Beharry, K. Gyomerey, J. Hwang, L. Morikawa, I. Naruszewicz, and A. Tilups.

This work was supported by the Canadian Cystic Fibrosis Foundation (CCFF) Research and Development Programme III, the Canadian Genetic Disease Network, the Howard Hughes Medical Institute International Scholar Program, a Group grant from the Canadian Medical Research Council (MRC), the Sunnybrook Trust for Medical Research, and the Hospital for Sick Children (HSC) LungBased Gene Therapy Programme. L.-C. Tsui is the Sellers Chair in Cystic Fibrosis Research and a MRC Senior Scientist. A.K. Tanswell is the HSC Women's Auxiliary Chair in Neonatology. C.E. Bear is a MRC Scientist. H.M. O'Brodovich was a Career Investigator of the Heart and Stroke Foundation of Ontario, and R. Iles was a CCFF Fellow, during the tenure of these studies.

\section{References}

1. Welsh, M.J., L.-C. Tsui, T.F. Boat, and A.L. Beaudet. 1995. Cystic fibrosis. In The Metabolic and Molecular Basis of Inherited Disease. C.R. Scriver, A.L. Beaudet, W.S. Sly, and D. Valle, editors. McGraw-Hill, Inc., New York. 3799-3876.

2. Davis, P.B., M. Drumm, and M.W. Konstan. 1996. Cystic fibrosis. Am. J. Respir. Crit. Care Med. 154:1229-1256.

3. Riordan, J.R., J.M. Rommens, B.-S. Kerem, N. Alon, R. Rozmahel, Z. Grzelczak, J. Zielenski, S. Lok, N. Plavsic, J.-L. Chou, et al. 1989. Identification of the cystic fibrosis gene: cloning and characterization of complimentary DNA. Science. 245:1066-1073.

4. Quinton, P. 1996. Cystic fibrosis: a disease in electrolyte transport. FASEB (Fed. Am. Soc. Exp. Biol.) J. 4:2709-2717.

5. Khan, T.Z., J.S. Wagener, T. Bost, J. Martinez, F.J. Accurso, and D.W. Riches. 1995. Early pulmonary inflammation in infants with cystic fibrosis. Am. J. Respir. Crit. Care Med. 151:1075-1082.

6. Konstan, M.W., K.A. Hilliar, T.M. Norvell, and M. Berger. 1994. Bronchiolar lavage findings in cystic fibrosis patients with stable, clinically mild lung disease suggests ongoing infection and inflammation. Am. J. Respir. Crit. Care Med. 150:448-454.

7. Lamarre, A., B.J. Reilly, A.C. Bryan, and H. Levinson. 1972. Early detection of pulmonary function abnormalities in cystic fibrosis. Pediatrics. 50:291-298.

8. Snouwaert, J.N., K.K. Brigman, A.M. Latour, N.N. Malouf, R.C. Boucher, O. Smithies, and B.H. Koller. 1992. An animal model for cystic fibrosis made by gene targeting. Science. 257:1083-1088.

9. Clarke, L.L., B.R. Grubb, S.E. Gabriel, O. Smithies, B.H. Koller, and R.C. Boucher. 1992. Defective epithelial chloride transport in a gene-targeted mouse model of cystic fibrosis. Science. 257:1125-1128.

10. Rozmahel R., M. Wilschanski, A. Matin, S. Plyte, M. Oliver, W. Auerbach, A. Moore, J. Forstner, P. Durie, J. Nadeau, et al. 1996. Modulation of disease severity in cystic fibrosis transmembrane conductance regulator deficient mice by a secondary genetic factor. Nat. Genet. 12:280-287.

11. Kent, G., M. Oliver, J.K. Foskett, H. Frndova, P.R. Durie, J. Forstner, G.G. Forstner, J.R. Riordan, D. Percy, and M. Buchwald. 1996. Phenotypic abnormalities in long-term surviving cystic fibrosis mice. Pediatr. Res. 40:233-241.

12. Miller, S.A., D.D. Dykes, and H.F. Polesky. 1988. A simple salting out procedure for extracting DNA from human nucleated cells. Nucleic Acids Res. $16: 215$.
13. O'Brien, E.P., E.K. Novak, S.A. Keller, C. Poirier, J.L. Guenet, and R.T. Swank. 1994. Molecular map of chromosome 19 including three genes affecting bleeding time: ep, ru, and bm. Mamm. Genome. 5:356-360.

14. Comroe, J., O, Nissell, and R. Nims. 1954. A simple method for concurrent measurement of compliance and resistance to breathing in anaesthetized animals and man. J. Appl. Physiol. 7:225-228.

15. Fry, D.L., R.V. Ebert, W.W. Stead, and C.C. Brown. 1954. The mechanics of pulmonary ventilation in normal subjects and in patients with emphysema. Am. J. Med. 16:80-97.

16. Wilschanski, M.A., R. Rozmahel, S. Beharry, G. Kent, C. Li, L.-C. Tsui, P. Durie, and C.E. Bear. 1996. In vivo measurements of ion transport in longliving CF mice. Biochem. Biophys. Res. Commun. 219:753-759.

17. Hessel, E.M., A.J. Van Oosterhout, C.L. Hofstra, J.J. De Bie, J. Garssen, H. Van Loveren, A.K. Verheyen, H.F. Savelkoul, and F.P. Nijkamp. 1995. Repeated measurement of respiratory function and bronchoconstriction in unanesthetized mice. J. Appl. Physiol. 79:1711-1716.

18. Ewart, S., R. Levitt, and W. Mitzner. 1995. Respiratory system mechanics in mice measured by end-inflation occlusion. J. Appl. Physiol. 79:560-566.

19. Iles, R., H. Frndova, G. Kent, and H. O'Brodovich. 1996. Measurements of pulmonary function in mice. Pediatr. Pulmonol. 13:254a. (Abstr.)

20. McIlroy, M., and D. Tierney. 1963. A new method for the measurement of compliance and resistance of lungs and thorax. J. Appl. Physiol. 18:424-427.

21. Motoyama, E. 1977. Pulmonary mechanics during early postnatal years. Pediatr. Res. 11:220-223.

22. Knowles, M.R., A.M. Paradiso, and R.C. Boucher. 1995. In vivo nasal potential difference: techniques and protocols for assessing efficacy of gene transfer in cystic fibrosis. Hum. Gene Ther. 6:445-455.

23. Langridge-Smith, J.E. 1986. Interaction between sodium and chloride transport in bovine tracheal epithelium. J. Physiol. (Lond.). 376:299-319.

24. Clarke, L.L., B.R. Grubb, J.R. Yankaskas, C.U. Cotton, A. McKenzie, and R.C. Boucher. 1994. Relationship of a non-cystic fibrosis transmembrane conductance regulator-mediated chloride conductance to organ level disease in Cftr (-/-) mice. Proc. Natl. Acad. Sci. USA. 91:479-483.

25. Bedrossian, C.W., S.D. Greenberg, D.B. Singer, J.J. Hansen, and H.S. Rosenberg. 1976. The lung in cystic fibrosis. A quantitative study including prevalence of pathologic findings among different age groups. Hum. Pathol. 7: 195-204.

26. Oppenheimer, E.H., and J.R. Esterly. 1975. Pathology of cystic fibrosis. Perspect. Pediatr. Pathol. 2:241-278.

27. Sharp, J.T., and M.D. Hammond. 1991. Pressure-volume relationships. In The Lung: Scientific Foundations. R.G. Crystal, and J.B. West, editors. Raven Press, New York. 839-854.

28. Plopper, C.G., D.M. Hyde, and A.R. Buckpitt. 1991. Clara cells. In The Lung: Scientific Foundations. R.G. Crystal, and J.B. West, editors. Raven Press Ltd., New York. 215-228.

29. Forrest, J.B., and M.K.W. Lee. The bronchial wall: integrated form and function. In The Lung: Scientific Foundations. R.G. Crystal, and J.B. West, editors. Raven Press Ltd., New York. 792-739.

30. Cohen, J.C., S.L. Morrow, T. Ren, J. Wilson, and J.E. Larson. 1996. The developmental function of the cystic fibrosis transmembrane conductance regulator is associated with the nucleotide binding domain. Pediatr. Pulmonol. 13: 267a. (Abstr.)

31. Brody, J.S., and N.B. Kaplan. 1983. Proliferation of alveolar interstitial cells during postnatal lung growth. Am. Rev. Respir. Dis. 127:763-770.

32. Dunill, M.S. 1990. Pulmonary fibrosis. Histopathology (Oxf.). 16:321-329.

33. Penney, D.P., P.C. Keng, S. Derdak, and R.P. Phipps. 1992. Morphologic and functional characteristics of subpopulations of murine lung fibroblasts grown in vitro. Anat. Rec. 232:432-443.

34. Grubb, B.R., N. Vick, and R.C. Boucher. 1994. Hyperabsorption of $\mathrm{Na}^{+}$ and raised $\mathrm{Ca}^{2+}$ mediated $\mathrm{Cl}^{-}$secretion in nasal epithelia of $\mathrm{CF}$ mice. Am. $J$. Physiol. 266:C1478-1483.

35. Smith, J.J., S.M. Travis, E.P. Greenberg, and M.J. Welsh. 1996. Cystic fibrosis airway epithelia fail to kill bacteria because of abnormal airway surface fluid. Cell. 85:229-237.

36. Canessa, C.M., L. Schild, G. Buell, B. Thorens, I. Gautschi, J.D. Horisberger, and B.C. Rossier. 1994. Amiloride-sensitive epithelial $\mathrm{Na}^{+}$channel is made of three homologous subunits. Nature. 367:463-467. 